\title{
Following the law
}

\section{A guide for the perplexed graduate student doing research.}

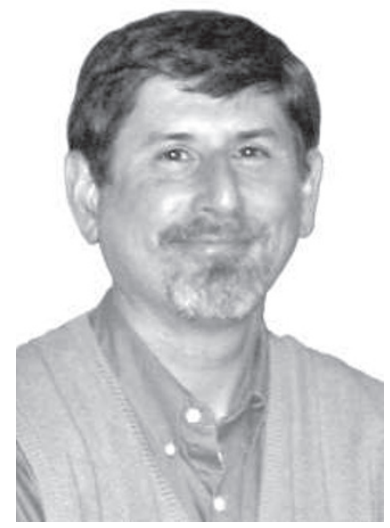

Irving P. Herman
Going to graduate school to pursue a doctorate is a major commitment of time and effort. It is not for everyone. Once in a graduate programme, choosing a research adviser is perhaps the most important decision a student can make. Likewise, choosing the right students is essential for the careers of advisers. It is obvious that mentors and students must have common research interests and compatible work habits. But it is sometimes less obvious that they must learn to communicate with each other. Developing a functional working relationship is important even between 'good' students and 'good' advisers, and this often takes some time.

In this spirit, I offer 20 'laws' as a guide to graduate students doing thesis research. Each contains sound advice about the facts of life in graduate research, particularly from the viewpoint of a thesis adviser. Several have been slightly exaggerated for effect, or are not to be taken too literally. Some clearly pertain to experimental research, although they have obvious counterparts for other types of research.
I developed these laws to help motivate some of the graduate students in my group, to explain how to be an effective student and to convince them that supervised research is a symbiotic (although not symmetric) interaction between student and adviser. I admit that I am not always successful in this endeavour.

I also use these laws as general advice for graduate students in

\section{"Supervised research is a symbiotic (although not symmetric) interaction between student and adviser."}

my department. All doctoral candidates in the department receive a copy of the laws when they enter our programme, to help them understand how to work with an adviser as they move from the undergraduate mode of taking courses to the graduate mode of conducting supervised research. These laws seem to resonate with my faculty colleagues, and several have posted them and used them.

Although the laws require no interpretation, students may understand them better by understanding their advisers better. Advisers, including my own students' adviser, love to recall the 'good old days' when they were graduate students. They all worked 20-hour days, seven days a week, and they never slept. They needed to build from scratch every instrument they used in their work and they thought of every idea in their theses. And, most importantly, they always, always, took to heart their advisers' every suggestion and acted on each promptly.

On a more serious note, there are some real overarching themes in the laws. In research, being right is paramount, and ideas and results must be evaluated using objective methods untainted by egos. Productive people are productive because they have good work habits. Students need to grow professionally and advisers need to assist them. The relationship between graduate student and adviser truly is symbiotic.

Irving P. Herman is a professor of applied physics at Columbia University, New York.

\section{THE LAWS OF HERMAN}

1. Your vacation begins after you defend your thesis.

2. In research, what matters is what is right, and not who is right.

3. In research and other matters, your adviser is always right, most of the time.

4. Act as if your adviser is always right, almost all the time.

5. If you think you are right and you are able to convince your adviser your adviser will be very happy.

6. Your productivity varies as (effective productive time spent per day $)^{1,000}$.

7. Your productivity also varies as $1 /$ (your delay in analysing acquired data $)^{1,000}$.

8. Take data today as if you know that your equipment will break tomorrow.
9. If you would be unhappy to lose your data, make a permanent back-up copy of them within five minutes of acquiring them.

10. Your adviser expects your productivity to be low initially and then to be above threshold after a year or so.

11. You must become a bigger expert in your thesis area than your adviser.

12. When you cooperate, your adviser's blood pressure will go down a bit.

13. When you don't cooperate, your adviser's blood pressure either goes up a bit or it goes down to zero.

14. Usually, only when you can publish your results are they good enough to be part of your thesis.

15. The higher the quality, first, and quantity, second, of your publishable work, the better your thesis.
16. Remember, it's your thesis. You (!) need to do it.

17. Your adviser wants you to become famous, so that he/she can finally become famous.

18. Your adviser wants to write the best letter of recommendation for you that is possible.

19. Whatever is best for you is best for your adviser.

20. Whatever is best for your adviser is best for you. 